

\section{Daftar Isi (Table of Content) Journal of Government
Civil Society}

\begin{tabular}{|c|c|}
\hline \multirow{3}{*}{$145-158$} & $\begin{array}{l}\text { Political Law's Reconstruction of Village Apparatus to Realize Independent } \\
\text { Village in Indonesia }\end{array}$ \\
\hline & Hartati $^{1}$, Pahrudin HM$^{2}$, Elita Rahmi ${ }^{1}$ \\
\hline & $\begin{array}{l}\text { ('Faculty of Law, Universitas Jambi, Indonesia) } \\
\text { ('Departement of Government Science, STISIP Nurdin Hamzah Jambi, Indonesia) }\end{array}$ \\
\hline \multirow{3}{*}{$159-179$} & $\begin{array}{l}\text { Policy of a Merit System to Make a Good and Clean Government in The } \\
\text { Middle of Bureaucratic Politicization }\end{array}$ \\
\hline & $\begin{array}{l}\text { Yahya Pandega Putra1, 2, Eko Priyo Purnomo, 2, Suswanta Suswanta1, } \\
\text { Aulia Nur Kasiwi1, }\end{array}$ \\
\hline & $\begin{array}{l}\text { ('Jusuf Kalla School of Government, Universitas Muhammadiyah Yogyakarta, Indonesia) } \\
\text { ('Department of Government Affairs and Administration, Universitas Muhammadiyah } \\
\text { Yogyakarta, Indonesia) }\end{array}$ \\
\hline \multirow{3}{*}{$181-199$} & $\begin{array}{l}\text { Smart Human Security: Economic Safety for Micro, Small and Medium } \\
\text { Enterprises (MSMEs) to Face The Impact of The Covid-19 Global Pandemic }\end{array}$ \\
\hline & Elyta $^{1}$, Warjio ${ }^{2}$, Ahmad Azrin Bin Adnan ${ }^{3}$ \\
\hline & $\begin{array}{l}\text { ('Faculty of Social and Political Sciences, Universitas Tanjungpura, Indonesia) } \\
\text { ('Faculty of Social and Political Sciences, Universitas Sumatera Utara, Indonesia) } \\
\text { ('Faculty of Business and Management, Universiti Sultan Zainal Abidin (UnisZa), } \\
\text { Trengganu, Malaysia) }\end{array}$ \\
\hline \multirow{3}{*}{$201-218$} & $\begin{array}{l}\text { Using The "Return on Investment" Strategy to Sustain Logistic Supply } \\
\text { Provider Toward Indonesia's Logistic Policy }\end{array}$ \\
\hline & Riska Rahayu $\mathbf{u}^{1,2}$, Eko Priyo Purnomo ${ }^{1,2}$, Ajree Ducol Malawani,1,3 \\
\hline & $\begin{array}{l}\text { ('1usuf Kalla School of Government, Universitas Muhammadiyah Yogyakarta, Indonesia) } \\
\text { ('Magister of Government and Public Affairs, Universitas Muhammadiyah Yogyakarta, } \\
\text { Indonesia) } \\
\text { ('Doctoral Program of Political Islam, Universitas Muhammadiyah Yogyakarta, Indonesia) }\end{array}$ \\
\hline \multirow{3}{*}{$219-228$} & $\begin{array}{l}\text { Indonesia Universal Health Coverage Implementation on University } \\
\text { Students }\end{array}$ \\
\hline & Adityo Pratikno Ramadhan'1, Budiyono Budiyonoㄹ, Djonet Santoso' ${ }^{1}$ \\
\hline & ('Sustainable Development Goals Center, Universitas Bengkulu, Indonesia) \\
\hline
\end{tabular}


The Local Government of Kulon Progo Regency Innovation in Subduing Capitalism through Community Empowerment

229 - 247 Muhammad Eko Atmojo ${ }^{1}$, Helen Dian Fridayani ${ }^{2}$

('Departement of Government Science, Universitas Muhammadiyah Yogyakarta, Indonesia)

('Departement of Political Science, National Cheng Kung University, Taiwan)

Land Administration Policy In Bantul and Sleman Districts

$249-272$

Subekti Widiyasno1, Dyah Mutiarin 1, Herdin Arie Saputra1, Ikhwan

Rahmatika Latif ${ }^{1}$

('Department of Government Affairs and Administration, Universitas Muhammadiyah Yogyakarta, Indonesia)

Increasing Local Own-Source Revenue through The Development of The Regional Tourism Sector

$273-291$

Harries Madiistriyatno', Ida Musdafia Ibrahim², Dudung Hadiwijaya ${ }^{3}$

('Program Studi Magister Manajemen Sekolah Tinggi Manajemen IMMI, Indonesia) (2Program Studi Manajemen Sekolah Tinggi Ilmu Ekonomi Y.A.I, Indonesia)

(3Program Studi Manajemen, Universitas Muhammadiyah Tangerang, Indonesia) 


\title{
Smart Human Security: Economic Safety for Micro, Small and Medium Enterprises (MSMEs) to Face The Impact of The Covid-19 Global Pandemic
}

\author{
Elyta $^{1 *}$, Warjio $^{2}$, Ahmad Azrin Bin Adnan ${ }^{3}$ \\ ${ }^{1}$ Faculty of Social and Political Sciences, Universitas Tanjungpura, Indonesia \\ ${ }^{2}$ Faculty of Social and Political Sciences, Universitas Sumatera Utara, Indonesia \\ ${ }^{3}$ Faculty of Business and Management, Universiti Sultan Zainal Abidin (UnisZa), Trengganu, Malaysia \\ *Email Correspondence: elyta@fisip.untan.ac.id
}

\begin{abstract}
This article aims to develop the concept of human security through economic safeguards for Micro, Small, and Medium Enterprises (MSMEs) in the face of the Covid-19 pandemic. The analysis was carried out using a qualitative approach. This article has found an effort to secure the economy for Micro, Small, and Medium Enterprises (MSMEs) in the face of the Covid-19 pandemic by integrating the hard skills and soft skills approaches. The hard skill approach is an effort made through technical matters, namely primary education in online-based entrepreneurship and training in business management based on Information, Communication, and Technology. Primary education on entrepreneurship and training in the form of technical supervision and management of ICT-based businesses in dealing with the Covid-19 pandemic. The soft skill approach is the provision of understanding and communication skills, especially the ability to conduct diplomacy so that people can have good diplomacy skills and through empathy-buying so that people through empathy can trust again to increase their purchasing power, especially to products from MSMEs. By the author, this method is called smart human security.
\end{abstract}

Keywords: Covid-19, smart human security, Micro Small And Medium Enterprises

\begin{abstract}
ABSTRAK
Artikel ini bertujuan untuk mengembangkan konsep human Secuity melalui pengaman ekonomi terhadap Usaha Mikro Kecil dan Menengah (UMKM) dalam menghadapi pandemi Covid-19. Analisis dilakukan dengan pendekatan kualitatif. Artikel ini telah menemukan upaya pengamanan ekonomi bagi Usaha Mikro Kecil dan Menengah (UMKM) dalam menghadapi pandemi Covid-19 dengan mengintegrasikan antara pendekatan hard skill dan soft skill. Pendekatan hard skill merupakan upaya yang dilakukan melalui hal-hal teknis yaitu pendidikan dasar dalam berwirausaha berbasis online dan pelatihan pengelolaan usaha berbasis Information, Communication, and Technology. Pendidikan dasar mengenai kewirausahaan dan pelatihan-pelatihan berupa teknis manajemen dan pengelolaan usaha berbasis ICT dalam menghadapi pandemi Covid-19. Pendekatan soft skill merupakan pemberian pemahaman dan kemampuan komunikasi khususnya kemampuan dalam melakukan diplomasi agar masyarakat dapat memiliki keahlian berdiplomasi dengan baik serta melalui empathy-buying agar masyarakat melalui empatinya dapat kembali percaya untuk meningkatkan kembali daya belinya terutama kepada produk dari UMKM. Oleh penulis, cara tersebut disebut sebagai smart human security.
\end{abstract}

Kata Kunci: Covid-19; smart human security; Usaha Mikro Kecil dan Menengah

Citation : Elyta, Warjio, and Ahmad Azrin Bin Adnan. 2020. “Smart Human Security: Economic Safety for Micro, Small and Medium Enterprises (MSMEs) to Face The Impact of The Covid-19 Global Pandemic." Journal of Government and Civil Society 4(2):181-199. 


\section{INTRODUCTION}

Human security is a case study of international development that is focused on directing towards human welfare (Sudiar, 2018). Security issues related to individuals or human security in Indonesia are no longer only related to military security, such as war and conflict. Now, this is also related to the condition of human security, including the economic security aspect of society. These conditions make individuals determine their well-being. Based on this, the scope of the human security concept has a close correlation between one sector and another (Ardiyanti \& Anwar, 2018). Human security appropriately shows individuals as the main focus on the global development agenda, a concept that was initially related to economics. As a result, securing society through this concept means building human capacity to overcome problems, including hunger, discrimination, illiteracy, poverty, disease, restrictions on political freedom, violence, and the economy. This paper focuses on economic issues for Micro, Small, and Medium Enterprises (MSMEs) in the face of the Covid-19 pandemic.

The economy of a country is supported by the optimization of Micro, Small and Medium Enterprises, after this referred to as MSMEs. This is because the individual has sought welfare independently and automatically indicated an impact on the economy of a country. According to the Law of the Republic of Indonesia, Number 20, the Year 2008 explains the definition of MSMEs that is a small company owned and managed by someone or owned by a small group of people with a certain amount of wealth and income. The Ministry of Cooperatives and Small and Medium Enterprises of the Republic of Indonesia, in 2017, reported that MSMEs had a share of $99.99 \%$ or 62.9 million units of the total MSME actors in Indonesia. While large businesses only have a market share of $0.01 \%$ or 5,400 units. Microbusinesses absorb around 107.2 million workers $(89.2 \%)$, small businesses 5.7 million (4.74\%), and medium businesses 3.73 million (3.11\%), while large businesses absorb around 3.58 million. Based on this accumulation, MSME absorbs 97\% of the national workforce, while large businesses only absorb about $3 \%$ of the total national workforce (Haryanti \& Hidayah, 2019).

Furthermore, the development of MSMEs in Indonesia currently faces challenges in developing and managing businesses due to a lack of access to capital. An SME needs to have a budget to start and establish industries, both for the production, operation, and marketing of industrial products. The production results that will be developed and marketed by MSMEs then face other challenges, this has resulted in $97.36 \%$ of MSME entrepreneurs being limited in marketing industrial products on a local scale (Global Business Guide Indonesia, 2018). Bringing up ideas and starting a business was allegedly not too difficult for SMEs, but maintaining the industry with proper management so that it could compete was the researcher's attention. The challenge is the availability of competent local businessmen resources, infrastructure to access markets on a broader 
scale, and the selling points of the industrial products to compete with the products of other industries.

MSMEs are increasingly felting these problems in the face of the Covid-19 pandemic that has been felt since the end of 2019. Covid-19, which was initially known as the Coronavirus, has initially been an epidemic in Wuhan, China, at the end of 2019. The virus then spread rapidly throughout the world is infected by the virus and makes its status become a pandemic. The situation was determined by the World Health Organization (WHO) on March 11, 2020. The pandemic then became an opponent in the maintenance of human security at the global level. The ongoing Covid-19 pandemic was allegedly able to have a long-term impact on the economic slowdown in Indonesia.

In general, Indonesia's economic growth has declined due to Covid-19 pandemic. According to the Minister of Finance, Sri Mulyani Indrawati, this year's percentage of global economic growth is projected to slow down to $2.8 \%$. This condition is similar to the global financial crisis that occurred in 2008 (Fauzia, 2020). The deteriorating condition of the Indonesian economy is also a result of the weakening of economic conditions at the global level in the face of the Covid-19 pandemic. Besides, government policies to prevent the spread of Covid-19 through work from home, self-quarantine, or physical distancing make people less likely to leave the house. This has a national impact on the weak purchasing power of the people in the offline market.

Changes in policies that prioritize people with underdeveloped economies, including in the border region, do not have a significant impact on the economic conditions of the people so that they still experience poverty (Herlan \& Elyta, 2020). Faced with this, the government has formed policy coordination between monetary authorities such as Bank Indonesia (BI), the Financial Services Authority (OJK), and business actors in the real sector, such as MSMEs. This was done to maintain the strengthening of the Indonesian economy so that it remained on the development goals and the country's economy. The policy adopted is prioritizing development in five sectors, namely human resources, infrastructure development, economics, regulation or regulation, and simplification of bureaucracy. It is meanwhile related to the health sector fully submitted to the Ministry of Health to rearrange the budget needed during the Covid-19 period.

In the microeconomic sector, MSME is the most vulnerable sector because its daily economic income relies on daily money circulation (Julaika, 2020). For this reason, MSME actors must be sensitive to social-economic changes that occurred in the Covid-19 pandemic. Reduced demand in the offline market or physical market occurs because of directives from the government to implement physical restrictions (physical distancing) and reduce activities outside the home during the Covid-19 pandemic has not subsided. The purchasing power of the people turning to online media is a challenge and opportunity for SMEs. 
To increase the economic security of MSMEs in dealing with Covid-19, the researchers analyzed the condition through aspects of hard skills and soft skills. Developing hard skills requires a focus on MSME development strategies so that they can then be useful for the country's economy in building sustainable MSME competitiveness in the domestic and international markets. In addition to hard skills, MSME resource development strategies are equipped with soft skills. Soft skill development is not always interpreted as self-ability because it also requires a broader definition to bring competitive advantage. To achieve these soft skills, the strategy for developing MSMEs is carried out by diplomacy training and provides insights on the morality that business actors must possess and selfspirituality in entrepreneurship during the Covid-19 pandemic.

Previous studies that have been carried out related to efforts in the economic sector conducted in the face of a virus or pandemic outbreak are studies conducted in the European region. The study examines economic governance to respond to unprecedented economic challenges due to the coronavirus outbreak. Based on the study found a collective action by the state government by implementing policies through the European Central Bank to continue the unconventional monetary policy to overcome the crisis, primarily through asset purchases. The political implications of the two Union Economic and Monetary asymmetries discussed in this introduction are striking in the current context. The policy and institutional effects of this asymmetry remain the subject of increasingly fierce debate (Howarth \& Verdun, 2020).

Other studies have been carried out by analyzing the emergency governance of international organizations by combining security theory (securitizing) with a legal approach in exceptional circumstances. The research shows how the WHO's extraordinary response to the severe acute respiratory syndrome 2003 was the SARS virus. The emerging crisis then paved the way for the institutionalization of emergency powers in the organization and contributed to securitizing the 2009 outbreak of swine flu as a global pandemic. However, the WHO crisis administration has also triggered the internal and external processes of constitutional conflict (Hanrieder \& Kreuder-Sonnen, 2014). This paper is the development of the concept of human security by focusing on MSME economic security against Covid-19 through hard skills and soft skills.

\section{RESEARCH METHODS}

This study uses qualitative research methods to demonstrate qualitative frame sampling. The process of collecting data is done by studying literature from articles in journals, online news, and books relating to human security and Covid-19. Furthermore, the data components are analyzed with the scope of the data collection, reduction, data presentation, and interactive conclusions drawn during and after data collection. After seeing the studies that have been mentioned and looking at the background of the problem 
in this study, the novelty of this research is that the researcher conducts an analysis using the concept of human security by focusing on MSME economic security against Covid-19 through hard skills and soft skills.

\section{RESULTS, DISCUSSION, AND ANALYSIS \\ Evolution of Security Concepts: From Traditional Security Concepts to Human Security Concepts}

Until the Cold War, which at that time divided the world into two opposing camps under the power of two superpowers, the United States and the Soviet Union, the concept of security was understood only in discussions relating to the military. Security is traditionally defined as a safe condition that is felt from war and military, so it is called traditional security. The conventional concept of security assumes that the object of reference to security is the state, and the structure of international anarchist systems can explain why a country tends to increase its military capability to secure its sovereignty. This situation raises suspicion in interactions between nations that stem from the security dilemmas faced by all countries. In anticipating what is done by each country, a miscalculation can create conflict and even war between nations (Baylis, Smith, \& Owens, 2012).

Thus it is clear the traditional security concept is interpreted as safe from outside attacks and safe from efforts to break the territorial integrity. So it can be explained that in the conventional theory, security is more interpreted as an effort to protect the territorial integrity of the country from threats that arise from outside, the definition of security is only aimed at how the state strengthens itself in its efforts to deal with threats from outside. Here the state (country) is the subject and object of efforts to pursue security interests. Traditional security issues are perceived and handled in the context of interstate relations, namely to maintain and protect the security of a country from threats (especially military threats) coming from other countries (this is called traditional security) so that a country's military capability to defend itself is a must in a traditional security perspective.

Meanwhile, The Copenhagen School tries to broaden the object of a referent object to security issues by no longer talking about state security but also concerning human security (Buzan, Weaver, \& Wilde, 1998). Thus the concept of human security marks a shift in international relations, namely changes in norms about the relationship between state sovereignty to individual security and broader human rights. The concept of human security is known to be known through a report from the United Nations (UN) or known as the United Nations (UN) through one of its bodies, namely the United Nations Development Program (UNDP). Based on the report contains the term human security 
(human security), which is different from the concept of security that was previously widely known. The concept of human security has a focus, which is to protect the sovereignty of the country, which is different from traditional security concepts, which only focus on protecting citizens from war and conflict.

UNDP put forward the main thought of the concept of human security. Is that the end of the cold war should also change the security paradigm from nuclear security to human security. This UN agency believes that there are more conflicts within countries (within nations) than between countries (international disputes). For many humans, feelings of insecurity are born more from everyday life than due to specific world events. In the final analysis, human security is synonymous with children who do not die, diseases that do not spread, work that is not stopped, ethnic conflicts that do not lead to violence.

Human security is not dealing with weapons instead of dealing with human life and dignity. The Copenhagen School and UNDP then included aspects beyond traditional awareness of security studies such as hunger, land and forest fires, dehumanization, poverty, infectious diseases such as HIV/AIDS, SARS, and bird flu, narcotics, human rights (HAM) and so on as part of security studies. The security study was initiated as a response and response to dealing with humanistic issues in human security such as the problems of victims of post-conflict and post-violence displacement, trafficking of women and children, food crisis, terrorism, and illegal trafficking, cases of violations of Human Rights (HAM), and others (UNDP, 2018).

Based on the opinions of the experts, it is clear that security can no longer only revolve around traditional security; indeed conventional security threats are essential, but human security is urgent, the state can be threatened if individuals are threatened, efforts to achieve security are no longer solely by using military force, a lawsuit against traditional perspectives gives birth to new values and norms that the essence of security is human security. The new security perspective is based on the demand to prioritize human security, non-military issues not only threaten individuals who live in a country but also threaten the integrity of the state, therefore, human security is essential to be adopted.

\section{Pandemic Covid-19 Impacts on Society}

At the end of 2019, the world was shocked by the news of a coronavirus outbreak in the city of Wuhan, China. This causes an increase in pneumonia cluster sufferers or commonly called wet lungs caused by the Coronavirus. The Coronavirus that attacks has a massive number in a group of viruses. The name corona is derived from the crown-like shape the virus has, in the body of the virus it contains a genetic nucleus that is found surrounded by a layer called a protein nail. There are many types of coronaviruses, and each of them gives different symptoms. Symptoms caused by breathing problems and can also be bleeding in the digestive system called gastrointestinal, which can become 
more severe, such as pneumonia. The level of danger of symptoms is determined by the type of virus because not all coronaviruses are at the same danger level. Some symptoms can cause severe illness, such as acute respiratory syndrome.

According to the Science Alert report, WHO previously called the Corona Virus an acute respiratory disease with the name 2019-nCov. But the WHO finally gave where Covid also turned out to be an abbreviation of Corona Virus Disease, and 19 meant 2019 (Kurnia, 2020). In 2003 the Coronavirus was first discovered in China and the Middle East. Meanwhile, the coronavirus novel was found in a group of people with pneumonia in China and is thought to have close contact with marine and terrestrial animals that were used as food by people in the area. This Coronavirus is a virus that spreads from those who are infected to the closest family and close relatives, including health workers who serve them also.

Currently, the Coronavirus has spread to many countries, as evidenced by the many cases that have occurred, the spread is thought to be due to animal circulation, and then this virus can infect or spread to humans if interacting at close range. This virus also mutates and causes overflow or transmission to humans; another thing that can increase the risk of contracting is direct contact with animals that carry the Coronavirus, for example, murska, camels, and mongoose. Shelter animals infected with the Coronavirus do not yet know how to move the Coronavirus, but indeed can be transmitted through fluids when infected with sneezing or coughing or through a virus contaminated place.

People infected with Covid-19 can be further examined using Polymerase Chain Reaction (PCR), which is an examination using genetic fingerprints. Until now, there has not been found an antidote that can eradicate this virus, and what is at present is drugs and equipment to support the infected body so that it can withstand the effects of the Covid-19 virus. Speaking of vaccines, a particular vaccine for this virus is still under development and even then only for how to prevent the virus from being too aggressive in its transmission. Although this virus is still limited in terms of spread it has been determined that minimum cleanliness must be met to protect our bodies from being infected such as wearing a mask, avoiding people affected with sneezing or coughing, wearing a mask is one of the things that may be mandatory and always maintain personal hygiene we or by applying other self-protective equipment. The easiest is still to wash your hands with soap.

Another action we can take is to minimize direct contact with animals. If you want to cook animal meat, then try to cook it thoroughly, and if you feel unwell, then immediately seek first aid such as eating medicine yourself or going to the nearest clinic. Then remember any place that was visited during the trip then consult with the doctor you met. Unwittingly this is thought to be able to keep humans from Covid-19 contamination in its spread, which can be said to be very fast. 
Additional interventions, including expanded critical care capabilities and herd immunity. Longitudinal serological studies are needed to determine the level and duration of immunity to the Covid-19 pandemic. Even if there is a real elimination, monitoring of the acceleration of handling of the Covid-19 pandemic must be maintained because the Covid-19 pandemic is predicted to last until the end of 2024 (Kissler, Tedijanto, Goldstein, Grad, \& Lipsitch, 2020). For this reason, MSME entrepreneurs need to adapt and innovate to be able to continue their business.

\section{Smart Human Security}

Indonesia's economic security of MSMEs in the face of the Covid-19 pandemic integrates two approaches that refer to the concept of human security. The plan is hard and soft skills and the embodiment of smart human security. This paper explains that smart human security is a combination of hard skills through physical strength and soft skills through persuasion and feel connectivity. Smart human security is carried out by strengthening the capacity of MSMEs by combining elements of hard skills and soft skills in a mutually reinforcing way. Thus, Smart Human Security is a Strengthening of MSME economic security by combining elements of hard skills and soft skills for MSMEs in dealing with Covid-19. The Smart Human Security model is further elaborated in the following explanation.

Human Security through Hard Skill Training in Micro, Small and Medium Enterprises in Dealing with Covid-19

The MSME economic safeguard strategy within the scope of hard skills can be developed through technical matters such as education and training for MSME players online. Provision of knowledge to SMEs is made by providing training that can improve hard skills in the form of primary education on entrepreneurship and training in the way of technical management and business management. The training is explained as follows:

1. Basic Education in Entrepreneurship Based on Online Information, Communication, and Technology (ICT)

MSME creative efforts in Indonesia have experienced positive growth in the last three years, which has helped to increase employment absorption. This sector created employment for 16.4 million people in 2017. This shows the enormous potential of empowering well-managed local businesses when MSMEs are successfully developed and then has an impact on increasing competence to compete at the national and international level so that MSMEs can become economic backers Indonesian which can be seen in the following diagram. 


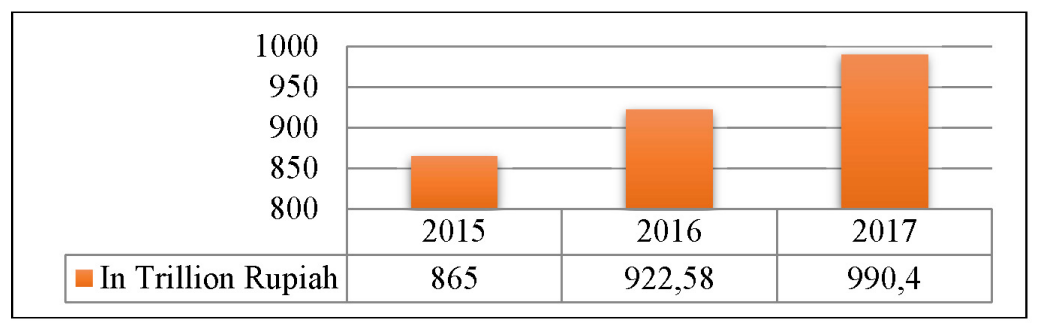

Figure 1. Growth of SMEs in Indonesia in 2015-2017

Source: (Global Business Guide Indonesia, 2018)

The development of the Indonesian economy, especially in the digital economy has been developing in the last ten years. It is projected that by 2020 Indonesia's digital economy will grow to 500 trillion rupiahs and reach 2,000 trillion rupiahs by 2025 (Warta Ekonomi, 2020). But with the advent of the Covid-19 virus, it has had an impact on the world economic sector. This is due to China as the country where the virus began to spread the axis of world trade. In addition to the global economy, the national economy is also affected by the virus. The impact on the national economy sector is no exception to the digital economy sector.

With the existence of physical distancing and work from home policies, people make economic and business activities online and then also provide opportunities for the development of the digital economy. Physical distancing policy is to maintain physical distance between individuals without being socially separated. Work from home policy means that people are encouraged to work from home. The field of work that continues to work in the office is to work in public services and health. Whereas other work, including business economics, also did not escape the policy of working from home by switching to the utilization of the digital economy.

Hard skills are science, technology, and technical skills. The MSMEs' economic safeguard strategy facing the Covid-19 pandemic through hard skills in the form of basic education in entrepreneurship collaborates between science and practice or training as a form of developing MSMEs in participation in public life. Basic education training in entrepreneurship contains basic knowledge to start a business. SMEs are positioned as participants to receive entrepreneurial material and turn on the resources of local entrepreneurs with technical expertise in the business as well as stimulate innovation and creativity of local entrepreneurs' resources to start doing business without being hampered by the impact of the Covid-19 pandemic. Basic education is carried out online through applications such as zoom, google meet, as well as social media such as Whatsapp and telegram. It is also done through a call for a paper or webinar program (seminar 
through the website). Thus, SMEs are motivated to learn about the importance of the digital world in economic and business development, including through basic education in online-based entrepreneurship.

2. Business Management Training Based on Information, Communication, and Technology (ICT)

Indonesia's creative sector in 2018 has reached 6.25\% and employs 16.70 million workers. Creative Economy Agency (Bekraf) makes work patterns to increase readiness in several industries such as investment in fashion, handicraft, and application and game development, in addition to culinary sub-sector. The level of investment readiness released by Bekraf has a function that assesses the level of investment sector readiness and anticipates the lifestyle of technology and competition in the market (Global Business Guide Indonesia, 2018).

Efforts to prevent the spread of the impact of Covid-19 have brought business opportunities as well as threats to SMEs. For this reason, a development strategy to support the economic security of MSMEs in the face of the Covid-19 pandemic is to expand knowledge and provide information to the public in managing and managing their businesses so that MSMEs can prepare themselves by designing strategies to deal with open access to international markets by bringing in investors to increase their excellence and capital in running their business even though they were affected by the Covid-19 pandemic. Among these is through the Unified Communication (UC) innovation that is suitable for companies or startups that develop online business platforms.

With the increase in social and economic competition, it has an effect on MSMEs that are still weak. The decline in the selling value of the resulting product so that there is a shift in market share to other businesses that are considered more attractive or more affordable because of the similarity of production results but have different marketing tariffs. The strategy is when the product is in demand and productive to be marketed to the target market segment with consideration of market interest and safety of the product on consumer health. This means that MSMEs first analyze the demand and the consumer market. Meanwhile, SMEs do not yet master the technology for marketing. It is undeniable that the mastery of technology for marketing today is essential in the modern economy (Elyta \& Razak, 2019). Based on the training that has been carried out, the participants of the SMEs are taught to manage their businesses based on Information, Communication, and Technology (ICT).

ICT is an approach that refers to all technologies used to handle telecommunications, broadcast media, intelligent building management systems, audiovisual processing and transmission systems, and network-based control and monitoring functions. Thus, ICT is 
different from IT (Information and Technology) because the scope of ICT is broader. In other words, IT is part of ICT. ICT encompasses internet-supported and mobile environments that are powered by wireless networks. It also includes traditional technologies, such as mobile phones, radios, and television broadcasts, where they are still widely used today along with cutting-edge ICT pieces such as artificial intelligence and robotics (Asociación Europeyou, 2019). ICT components have continued to develop for decades and continue to experience innovation as a form of adaptation to the development of the digital economy.

The widespread use of ICT now in the transition era between traditional industries and the Industrial Revolution 4.0 era is part of modernization, which is demanded by the people in the Covid-19 pandemic. During this period of community transformation, there were profound changes that permeated through almost all aspects of community life and society as a whole. The conditions for geographical decentralization of each company's products are created, and the global presence of products and services in the worldwide market is ensured. The MSME then exploits all business opportunities and opportunities in such new circumstances, creating loyal customers, and increasing the overall efficiency of the business. However, to optimize ICT, it is known that the SMEs then face the following challenges.

Table 1. Challenges When SMEs Sell Their Products Outside The Country

\begin{tabular}{lccc}
\hline \multicolumn{1}{c}{ Challenge } & $\begin{array}{c}\text { Small } \\
\text { Business }\end{array}$ & $\begin{array}{c}\text { Medium } \\
\text { Business }\end{array}$ & Average \\
\hline $\begin{array}{l}\text { High product shipping costs when sold } \\
\text { Complaints and disputes when selling }\end{array}$ & $8,9 \%$ & $12,5 \%$ & $10,7 \%$ \\
$\begin{array}{l}\text { Adjustments and labeling for sale to other } \\
\text { countries }\end{array}$ & $6,4 \%$ & $10,9 \%$ & $8,65 \%$ \\
$\begin{array}{l}\text { Lack of knowledge of foreign languages } \\
\text { when communicating with customers }\end{array}$ & $1,1 \%$ & $11,9 \%$ & $8,35 \%$ \\
$\begin{array}{l}\text { Limitation of sales by MSME partners to } \\
\text { other countries }\end{array}$ & $8,6 \%$ & $1,9 \%$ & $1,5 \%$ \\
\hline
\end{tabular}

Source: (Radivojevic, Djekic, \& Spasic, 2019)

The impact of ICT has seen a positive influence on the company's daily operations in the market. New business concepts, management methods, and the functioning of business entities emerged. Communicating with consumers is much faster, much more straightforward, where purchases are realized at a much lower cost. Large amounts of data and documents become globally accessible, allowing it to be sent to the farthest places in the world. For this reason, the reason for ICT-based business management training is essential for MSMEs because generally, the people who act as entrepreneurs 
convey information through their products to consumers with a broader range, for example, related to price and product quality. To compete in the global arena, MSMEs must adapt themselves to upgrade themselves so that they can understand and use ICT for the digital economy properly.

Human Security through Soft Skill Training in Micro, Small and Medium Enterprises in Dealing with Covid-19

Collaboration in ineffective creative business groups shows essential interpersonal skills or soft skills in managing a business. Thus soft skills are self-management skills that can optimally increase competence in interacting with others and regulating self-attitude in acting. Based on the aspects that have been described, the researcher identifies that two soft skills are most needed in managing MSMEs to support the digital economy of MSMEs in facing the Covid-19 pandemic, namely through diplomacy and morality-empathy skills in entrepreneurship. That is, to improve competence as an embodiment of the MSME development strategy during the Covid-19 pandemic, then it is done through the development of hard skills and soft skills. The development has been carried out and is going well following the norms prevailing in society related to ethics in dealing with other SMEs in the international market.

Furthermore, the MSME development strategy on the soft skills aspect to support the digital economy of MSMEs in dealing with Covid-19 is carried out by providing understanding and communication skills, especially the ability to conduct diplomacy so that the public can have good diplomacy skills. The strength of diplomacy and empathybuying applied to develop MSMEs in this study is explained in soft skills training in the following aspects:

\section{Diplomacy (Communication Skills in Entrepreneurship)}

At the G20 Extraordinary Conference (Summit) Summit, the country's leaders agreed to fight Covid-19 and counter its impact on the weakening of the world economy. All G20 member countries will allocate research funds of USD 4 billion or around 64 trillion rupiahs for the discovery of the Covid-19 vaccine (Setyaka, 2020). Global Economic Growth (PEG), according to international institutions, has decreased between $0.9 \%-1.25 \%$, which was estimated to be $3.3 \%$ (Forbes, 2020). Facing the global and national economic impact of the Covid-19 pandemic, the government has made economic policies, namely through trimming the State Budget (APBN) and the Regional Budget (APBD), which are not prioritized budget plans. Some non-priority budgets, such as meeting budgets and official travel budgets, can be diverted. The budget is then allocated for the needs of sectors that are directly affected by Covid-19, such as the health and economic sectors. 
Besides, to adjust the policy of physical and work limitation from home, which helped make MSME actors unable to maximize their business through direct meetings between buyers and sellers, the government then formed a policy that helped affected MSME conditions. Based on the research, it is known that the system is through a decrease in interest and postponement of installments below the value of 10 billion rupiahs separately for MSMEs provided by the state through the Financial Services Authority (OJK) for a year. The policy was strengthened through Government Regulations instead of Laws (Perpu) on State Financial Policies and Financial System Stability for Handling Covid-19.

Meanwhile, on a global scale, there are more than 200 countries, including Indonesia, facing the Covid-19 pandemic. The dynamics of the global economy began to face an investment crisis, a decline in the number of tourist visits, to the disruption of the export and import process. These things also have an impact on MSMEs. This is due to policies that demand that people stay at home and reduce outside activities. Schools were closed, employees mostly had to work at home, tourist attractions and entertainment had to be closed. With the cessation of this activity, small stalls around the location will stop their income.

In addition to domestic economic policies, macroeconomic, political relations also become the spotlight of the Indonesian government. It is not only diplomatic relations between Indonesia and China that are affected but also between Indonesia and other countries and even between China and other countries. The regional quarantine policy (lockdown) has an impact on the world economy and also indirectly impedes economic development for SMEs.

But the opportunity behind the policy of physical restrictions and reducing the activity outside the home, people at various levels are required to be able to optimize the use of digital information technology that is connected via the internet. This is directly an application of the Industrial Revolution 4.0. Bilateral relations between countries must still be established even though the internet network. Likewise, trade practices must be able to optimize the use of e-commerce because, during this Covid-19 pandemic, the public cannot rely on face-to-face transactions so that it switches to digital business transactions. Thus knowledge of the internet network and the maximization of products offered through digital containers is essential. This needs to be also done by SMEs so that communication can be established smoothly and be able to re-increase the number of consumer demand.

Based on the opinions that have been presented by researchers, the policy becomes diplomacy, including the ability to communicate well in diplomacy, having a role in developing the economy. In the development of MSMEs, the state undertakes economic diplomacy between countries involved, such as carrying out commercial activities, through e-commerce. This ability is what researchers try to develop in the community, especially 
SMEs. Technical expertise alone is not enough to compete in international markets. Still, MSMEs are required to have competence in building images, building relationships, and attracting market share through good diplomacy in global markets. Good and appropriate dissemination and understanding of diplomacy in the business world without causing conflict is applied to develop MSMEs.

Economic diplomacy is closely related to the economic problems faced by one country with other countries relating to the economy or politics of a country. It cannot be separated from the domestic issues of a country with those influenced by various business circles or business actors (Suwarno, 2019: 24). Economic diplomacy is defined as a way of interacting with each country to reach a mutual agreement. Because in creative endeavors, the community is required to have these soft skills so that MSMEs are ready to face the international market with the capabilities they have based on the digital economy amid the Covid-19 pandemic. Diplomacy is essential because business actors will deliver it to the team and the management of the business unit.

Soft skills have a generic nature and are independent of work or industry. They have better self-management, self-motivation, empathy, and social skills (Tsey et al., 2018). Then this diplomacy training began by focusing on the self-management of local entrepreneurs in their ability to communicate well to convey the intentions and objectives of the business both in the selection of business partners and the marketing of business results. The understanding carried out in the form of socialization by gathering the business community as well as those who are just about to start a business as participants in this training to be given materials related to diplomacy and information about entrepreneurship. Equipped with good communication skills through training provided, the SMEs feel the ease in conducting diplomacy through communication in the future entrepreneurship. This digital-based diplomacy had an impact on the development of MSMEs in the face of the Covid-19 pandemic.

\section{Empathy-Buying}

Strengthening the economy in entrepreneurship is essential for the national interest (Brown \& Grävingholt, 2016). The business world is a very fierce field of competition; some individuals or groups do anything for profit. However, only business players with professional spirit can win. Business actors have confidence in consumers, as well as consumers and confidence in international market opportunities. To get support, trust and profit are to increase empathy. It cannot be separated from the life and success of the owner of life; empathy gives psychic strength to local entrepreneurs.

Soft skill in economic security, one of which is seen when facing the Covid-19 pandemic is through government policies in implementing physical distancing and implementing 
quarantine. Market activity has also been affected by the policy. Besides, the public response to the policy would become panic-buying. In the first week of implementing the policy, the public bought up goods in the market so that the goods would run out quickly. Not only the necessities, the availability of masks as protective equipment also became scarce and caused the price to be very high. In the following week, the community had begun to calm down, and panic-buying no longer occurred as in the first week of the implementation of the quarantine policy.

Based on data obtained from the study, it was found that production decreased by $35 \%$ due to lockdown, which means that every month this policy spends 3 points on annual Gross Domestic Product (GDP) (Sibony, 2020). Since March 2020, countries in the world have implemented a lockdown policy, namely the policy of isolating the population and its territory from and to certain countries or from one region to another in a country. The locking up of the area is applied in total by various countries in Europe and India and partially as used in Indonesia where the people work and study at home and by instructing social restrictions (social distancing) or by WHO is now replaced by the term physical restrictions (physical distancing). Besides, other policies through a ban to gather many people and make a minimum distance of 1.5 meters between people. The policy then encouraged people to apply the use of internet technology as a realization of the Industrial Revolution 4.0 into aspects of their lives during the pandemic. The world government took the policy based on the rapid rate of spread and deaths from Covid-19.

The widespread of the Covid-19 virus is beginning to influence consumer confidence in its purchasing power and the domestic business economy. The decline is because people are worried about the availability of jobs as well as income conditions. These two things are interrelated. Based on research, the drop in purchasing power confidence from the public is a psychological impact of Covid-19. Based on the results of a survey conducted by Bank Indonesia, it is known that the level of consumer purchasing power confidence during the Covid-19 pandemic is as follows.

\begin{tabular}{|ccccc|}
\hline $121,7 \quad 117,7$ & $109,6 \quad 105,5$ & 133,7 & 129,8 \\
\hline $\begin{array}{c}\text { Consumer Confidence } \\
\text { Index }\end{array}$ & $\begin{array}{c}\text { Economic Condition } \\
\text { Index }\end{array}$ & $\begin{array}{c}\text { Economic Condition } \\
\text { Expectation Index }\end{array}$ \\
\hline
\end{tabular}

Figure 2. Consumer Confidence Index (IKK), Economic Condition Index (IKE), and Covid-19 Period Economic Expectation Index (IEK) Source: (Nasional Kontan, 2020) 
From this index, other phenomena then emerge as the impact of the cessation of faceto-face activity in several shops and business centers. It also impacts MSMEs. The sector experienced a shortage of demand, and the number of buyer visits dropped dramatically (Latief, 2020). Thus, consumer purchasing power confidence determines a country's economic stability. The better the trust held by the public or consumers, the better the country's economic conditions. This includes also relating to the relationship between purchasing power and poverty levels, political power to guaranteeing the welfare of the people of the country (Herlan \& Elyta, 2020). For this reason, many MSME entrepreneurs began to look for other steps to continue to support their businesses, such as by producing fabric masks by government directives to be used by the community.

These aspects mean that MSMEs increase self-confidence by gaining strength or courage to compete and accept the challenges and risks that may be faced. The trick is to make exciting innovations in ways that do not violate the norms of society both in managing and marketing business results, especially during the Covid-19 pandemic, which led to reduced consumer confidence in buying. For this reason, the main goal of MSME entrepreneurs in running a creative business is to increase sales to gain more profit through ways that are carried out to include empathy values as a form of self-soft skills. This makes the strategy applied in the development of local entrepreneur's resources, namely soft skills through empathy-buying aspects.

Empathy-buying means that people also buy products from SMEs as a form of empathy and for the sake of building economic security. Because in a state of crisis due to Covid19, families with low incomes experience financial difficulties that depend on the government or social institutions. Aside from being a form of public awareness to fight panic-buying, empathy-buying is also a part of business exchange. The SMEs who implement the creations in their business are trying to strengthen their economic security. The government and social, humanitarian institutions have supported this empathybuying through solidarity funding to MSME actors affected by Covid-19. The empathy has supported the strengthening of economic security amid the Covid-19 pandemic.

\section{CONCLUSIONS}

Economic safeguards to MSMEs in dealing with the effects of the Covid-19 pandemic were carried out implicates by smart human security. The MSME financial safeguard strategy within the scope of hard skills can be developed through technical matters such as through basic education in online-based entrepreneurship and ICT-based business management training. Provision of knowledge to SMEs is made by providing training that can improve hard skills in the form of basic education implicates on entrepreneurship and training in the way of technical management and management of ICT-based businesses in the face of the Covid-19 pandemic. Meanwhile, the MSME economic 
safeguard strategy in the scope of soft skills can be developed to support the digital economy of MSMEs in dealing with Covid-19 by providing understanding and communication skills, especially the ability to conduct diplomacy so that people can have good diplomacy skills and through empathy buying so that the community through empathy, he can trust again to increase his purchasing power, especially to products from MSMEs.

\section{REFERENCES}

Ardiyanti, D., \& Anwar, A. (2018). The Dilemma of Human Security on Palm Oil Plantation in Indonesia. Jurnal Hubungan Internasional, 7(1), 60-68. https://doi.org/ 10.18196/hi.71125

Asociación Europeyou. (2019). What is Information and Communication Technology? Retrieved from Europeyou website: http:/ / europeyou.eu/es/what-is-information-andcommunication-technology/

Baylis, J., Smith, S., \& Owens, P. (2012). A Review of “The Globalization of World Politics: An Introduction to International Relations." Comparative Strategy, 31(5), 636. https:/ / doi.org/10.1080/01495933.2012.731976

Brown, S., \& Grävingholt, J. (2016). The Securitization of Foreign Aid. The Securitization of Foreign Aid, 1(45). https:// doi.org/10.1007/978-1-137-56882-3

Buzan, B., Weaver, O., \& Wilde, J. de. (1998). Security: A New Framework for Analysis. American Political Science Review, 93(4), 1010-1011. https://doi.org/10.2307/2586187

Fauzia, M. (2020). Sri Mulyani Akibat Corona Ekonomi Global Sama Seperti Krisis. Kompas. Retrieved from https://money.kompas.com/read/2020/03/02/190302126/ sri-mulyani-akibat-corona-ekonomi-global-sama-seperti-krisis-2008?page=all

Forbes. (2020). Morgan Stanley or Goldman? Down 35\%, Now MS Stock Will Win. Retrieved from Forbes website: https://www.forbes.com/sites/greatspeculations/ 2020/04/03/morgan-stanley-or-goldman-down-35-now-ms-stock-will-win / \#15d33b164bc7

Global Business Guide Indonesia. (2018). Indonesia's creative industry set to become the next economic powerhouse. Retrieved from Global Business Guide Indonesia website: http: / / www.gbgindonesia.com / en / manufacturing/article / 2018 / indonesia_s_creative_industry_set_to_become_the_next_economic_powerhouse_11835.php

Hanrieder, T., \& Kreuder-Sonnen, C. (2014). WHO Decides on The Exception? Securitization and Emergency Governance in Global Health. Security Dialogue, 45(4), 331-348. https://doi.org/10.1177/0967010614535833

Haryanti, D. M., \& Hidayah, I. (2019). Potret UMKM Indonesia: Si Kecil yang Berperan Besar. Retrieved from UKM Indonesia website: https://www.ukmindonesia.id/bacaartikel/ 62 
Herlan, H., \& Elyta, E. (2020). Model of Gawai Dayak Based-Social Capital in the Border of Sajingan Besar of West Kalimantan. Sosiohumaniora, 22(1), 46-54. https://doi.org/ 10.24198 / sosiohumaniora.v22i1.26042

Howarth, D., \& Verdun, A. (2020). Economic and Monetary Union at twenty: a stocktaking of a tumultuous second decade: introduction. Journal of European Integration, 42(3), 287-293. https://doi.org/10.1080/07036337.2020.1730348

Julaika, H. (2020). Halau Dampak Covid-19 ke UMKM, Pemerintah Terbitkan 8 Kebijakan. Media Indonesia. Retrieved from https://mediaindonesia.com/read/detail/301109halau-dampak-covid-19-ke-umkm-pemerintah-terbitkan-8-kebijakan

Kissler, S. M., Tedijanto, C., Goldstein, E., Grad, Y. H., \& Lipsitch, M. (2020). Projecting the Transmission Dynamics of SARS-CoV-2 Through The Postpandemic Period. Block Caving - A Viable Alternative?, 21(1), 1-9. https://doi.org/10.1016/ j.solener.2019.02.027

Kurnia, T. (2020). Alasan WHO Beri Nama Virus Corona Wuhan Jadi Covid-19. Liputan 6. Retrieved from https://www.liputan6.com/global/read/4177117/alasan-whoberi-nama-virus-corona-wuhan-jadi-covid-19

Latief, H. (2020). Solidarity-Buying: Pengaman Sosial Masa Pandemik. Retrieved from Ibtimes website: https://ibtimes.id/solidarity-buying-pengaman-sosial-masapandemik/

Nasional Kontan. (2020). Hati-hati tekanan daya beli akibat wabah Covid-19. Nasional Kontan. Retrieved from https://nasional.kontan.co.id/news/hati-hati-tekanan-dayabeli-akibat-wabah-covid-19

Radivojevic, J., Djekic, T., \& Spasic, K. (2019). Influence of Information-Communication Technology on Small and Medium Enterprises and Their Business.

Setyaka, V. (2020). Covid-19 dan Pengamanan Dunia. Retrieved from Kabar Kampus website: http:/ / kabarkampus.com/2020/04/covid-19-dan-pengamanan-dunia/

Sibony, A.-L. (2020). The UK COVID-19 Response: A Behavioural Irony? European Journal of Risk Regulation, (April), 1-11. https://doi.org/10.1017/err.2020.22

Sudiar, S. (2018). Pendekatan Human Security dalam Studi Perbatasan Negara. Jurnal Hubungan Internasional, 7(2), 152-160. https://doi.org/10.18196/hi.72139

Tsey, K., Lui, S. M. (Carrie), Heyeres, M., Pryce, J., Yan, L., \& Bauld, S. (2018). Developing Soft Skills: Exploring the Feasibility of an Australian Well-Being Program for Health Managers and Leaders in Timor-Leste. SAGE Open, 8(4), 1-13. https://doi.org/ $10.1177 / 2158244018811404$

UNDP. (2018). Indonesia's Human Development Index Series But Inequality Remains. Retrieved from UNDP website: http://www.id.undp.org/content/indonesia/en/ home/presscenter/ pressreleases/2017/03/22/indonesia-s-human-developmentindex-rises-but-inequality-remains-.html 
Warta Ekonomi. (2020). COVID-19 Makin Ganas, Ekonomi Digital Makin Berkembang? Retrieved from Warta Ekonomi website: https://www.wartaekonomi.co.id/ read276709/covid-19-makin-ganas-ekonomi-digital-makin-berkembang 
